\title{
近赤外光による脳血流の制御：基礎と臨床
}

\author{
苗代 弘 ${ }^{1}$, 和田 孝次郎 ${ }^{1}$, 魚住 洋一 ${ }^{1}$, 小林 弘明 ${ }^{1}$, 竹内 誠 ${ }^{1}$,

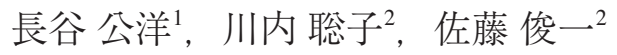 \\ ${ }^{1}$ 防衛医科大学校脳神経外科 ( \\ 2防衛医科大学校 防衛医学研究センター 情報システム研究部門 (テ359-8513 埼玉県所沢市並木3-2)
}

\section{Effects of Transcranial Near-Infrared Light on Cerebral Blood Flow}

\author{
Hiroshi NAWASHIRO, ${ }^{1}$ Kojiro WADA,,${ }^{1}$ Youichi UOZUMI, ${ }^{1}$ Hiroaki KOBAYASHI,${ }^{1}$ Satoru TAKEUCHI, ${ }^{1}$ \\ Kimihiro NAGATANI, ${ }^{1}$ Satoko KAWAUCHI, ${ }^{2}$ and Shunichi SATO $^{2}$ \\ ${ }^{1}$ Department of Neurosurgery, National Defense Medical College, \\ 3-2 Namiki, Tokorozawa, Saitama 359-8513 \\ ${ }^{2}$ Division of Biomedical Information Sciences, National Defense Medical College Research Institute, National Defense Medical College, \\ 3-2 Namiki, Tokorozawa, Saitama 359-8513
}

(Received January 6, 2012)

\begin{abstract}
Positive behavioral improvement has been observed following transcranial near-infrared light therapy in humans with chronic traumatic brain injury and acute stroke. We first examined the effect of $808 \mathrm{~nm}$ laser diode irradiation on regional cerebral blood flow (rCBF) in mice. An $808 \mathrm{~nm} \mathrm{CW}$ diode laser was applied to the hemisphere transcranially. Transcranial near-infrared laser irradiation increased rCBF by $30 \%$ compared to control value in mice. Near-infrared laser irradiation also provoked a significant increase in cerebral nitric oxide concentration. In the clinical setting, transcranial near-infrared lightemitting diode irradiation to the forehead in a patient with persistent vegetative state following head injury was done. $\mathrm{rCBF}$ showed focal increase of $20 \%$, compared to the pre-treatment value. The patient showed some improvement in his neurological condition after light-emitting diode therapy. Transcranial near-infrared irradiation might increase $\mathrm{rCBF}$ with some improvement of neurological condition in patients. Further study is warranted.
\end{abstract}

Key Words: Near infrared laser, Cerebral blood flow, Nitric oxide, Brain injury

\section{1.はじめに}

脳重量は, 体重の2\%程であるが, 脳血流量は心拍出 量の15-20\%を占める。重量\%に比し血流\%が10倍程と 圧倒的に多い理由は, 脳が多大の酸素とグルコースを消 費することにある，脳血流量は，灌流圧(平均動脈圧か ら頭蓋内圧を差し引いた圧) と血管抵抗の積に比例する が, 局所脳血流量は, 局所の神経活動と緊密に連動 (neurovascular coupling)している. シナプス間隙に隣接 して神経伝達物質の再取り达みや，神経栄養因子を出す 星細胞は, その一方の突起を細血管に絡めて, 神経興奮 と局所の脳血流の増加をカップリングさせている。神経 興奮に伴う局所脳血流の増加は, 局所の酸素需要を上回 る供給をもたらし，局所の酸素化へモグロビンの相対的 増加, 脱酸素化へモグロビンの相対的減少を来す。この 現象を, 核磁気共鳴法で画像化したものが, functional magnetic resonance imagingであり, 近赤外分光法 (NIRS: near-infrared spectroscopy)を用いて画像化したも
のが, 近赤外光イメージングである，近赤外線は，生体 透過性が高く，頭皮，頭蓋を介して大脳皮質の信号変化 を捉えうる，近赤外線の生体作用の一つとして，各種蔵 器における血流増加作用が知られているが ${ }^{1-3)}$, 脳血流 に及ぼす効果については，ほとんど報告がない。一方， 近赤外光の生体作用の一つとして, 神経保護効果が報告 されている ${ }^{4-10)}$ 。我々は, 近赤外光の脳血流量に及ぼす 効果を検討し報告して来た ${ }^{11,12)}$. 動物実験の基礎的な データと, ヒトにおける臨床デー夕を提示する. 将来的 に目指している近赤外光による脳血流の制御, 神経活動 賦活作用の可能性について言及したい.

\section{2. 近赤外線の生物学的効果 とくに中枢神経に対する効果}

まず，現在までに報告されている近赤外光の中枢神経 に対する生体作用と臨床研究の結果を示す. 1980年代 に, Karuが近赤外線の生物学的効果はcytochrome c 
oxidase (a terminal enzyme complex of the electron transport chain located in the inner mitochondrial membrane)のcopper anionsの吸収スペクトラムに一致することを見出し た ${ }^{13)}$ 。最近, 近赤外線が, mitochondrial optic neuropathy を改善するとの報告や ${ }^{8)}$, リンパ球に照射するとATPレ ベルが上昇するとの報告があり ${ }^{14)}$ ，近赤外線受容体とし てのcytochrome c説を支持する。近赤外線照射が, MPTP-treated miceのドパミン作動性神経細胞に対して保 護効果があるとの詳細な報告9), 近赤外線照射が, neuronal sprouting と migrationを促進するとの報告 ${ }^{10)}$ など もあり興味深い. しかし, cytochrome c以外の受容体の 存在を示唆する報告も散見され，未だ十分に解明されて いない.

\section{3. 近赤外線による脳虚血治療}

そもそも近赤外線照射で脳梗塞の治療が試みられ，部 分的成功を収めたとの報告 ${ }^{15,16)}$ に接したのが, 今回の研 究の動機である。発症後24時間以内の脳梗塞660症例を 対象にした無作為前向き二重盲検試験である。急性期脳 梗塞の患者を対象にした，対象患者選定基準は以下の如 くである.40-90歳. 発症から24時間以内. NIHSS 7-22 Informed consentが得られた患者. 除外項目, 除外 基準は, 頭蓋内出血. 発症前のmodified Rankin Scale (mRS)が3以上. 痤攣発症. 血糖值が $400 \mathrm{mg} / \mathrm{dl}$ 以上また は60 mg/dl以下。収縮期血圧が $220 \mathrm{~mm} \mathrm{Hg}$ 以上または $80 \mathrm{~mm} \mathrm{Hg}$ 以下。拡張期圧が $140 \mathrm{~mm} \mathrm{Hg}$ 以上または50 mm $\mathrm{Hg}$ 以下. 細菌塞栓の疑いがあるもの. 脳腫瘍. 頭皮に 問題があるもの. 血栓溶解療法を受けたもの. 頭蓋内に クリップ，バルブなどが植え込まれているもの．最近2 週間以内にPhotodynamic therapyを受けたもの.および 妊娠を除外した。 primary efficacy end pointは, 発症90日 目の良好な $\mathrm{mRS}(0-2)$. 他にmRS と National Institutes of Health Stroke Scale score (NIHSS) の改善度である。結 果：660例中331例が近赤外線治療を, 327例がsham control. 近赤外線治療群の内, 予後良好は120例 (36.3\%), sham control群の予後良好が101例 (30.9\%) $(p=0.094)$, odds ratio $1.38(95 \% \mathrm{CI}, 0.95$ to 2.00$)$. post hoc analysisを行ったところ, NIHSS16未満の比較的軽症 患者において, 統計学的有意に予後良好であるとの結果 が得られた $(p=0.044)$. 両群の死亡率, 重篤合併症発生 率は，それぞれ $17.5 \%$ と $17.4 \% ， 37.8 \%$ と $41.8 \%$ で有意差 は無かった ${ }^{16)}$ 。本臨床研究では, 近赤外線照射で脳梗塞 の機能予後を改善しうる可能性が示されたが，機序に関 しては全く不明で, 近赤外線照射による脳血流への影響 も全く検討されていない，そこで我々は，その機序を解 明すべく，近赤外線照射による脳血流への影響を検討す る基礎的研究を行った。

\section{4. 近赤外線による脸血流増加効果}

経頭蓋近赤外線レーザー照射によるマウス局所脳血流 増加を認めた(Fig. 1) 我々の研究を紹介する ${ }^{11)}$. 低出力

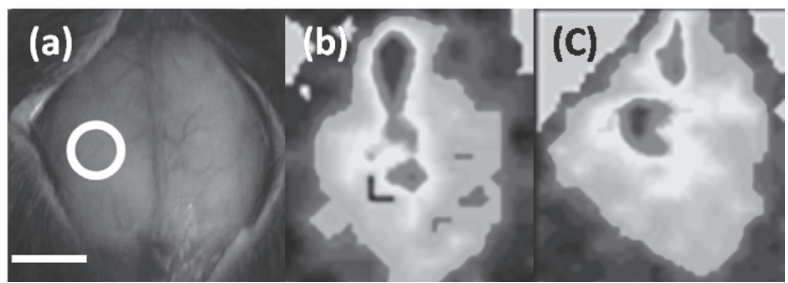

Fig. 1 Representative examples of the exposure field and perfusion images. (a) The exposure field was set to $3 \mathrm{~mm}$ in diameter $(2 \mathrm{~mm}$ posterior to and $3 \mathrm{~mm}$ left of the bregma). Scale bar is $5 \mathrm{~mm}$ in length. At the time of measurement, perfusion images were obtained (b: pre, c: 15 min after NIR laser irradiation). Targeted increase in cerebral blood flow of the irradiated field was observed (c).

近赤外線レーザー照射LLLTは， $0.8 ， 1.6,3.2 \mathrm{~W} / \mathrm{cm}^{2}$ の3 種類のエネルギー強度で検討した，LLLTをC57/BL/6Jマ ウス脳に経頭蓋的に照射し血流を測定する事で，マウス 脳LLLTにおける至適エネルギー強度を決定した。次に nitric oxide (NO) と脳血流の関与を精査する為に, LLLT 照射中の脳内NO濃度の変化を測定するとともに, nitric oxide synthase (NOS) 阻害剂である $N^{\mathrm{G}}$-nitro-L-arginine methyl ester(L-NAME), 神経型NOS特異的阻害剂である 7-nitroindazole (7-NI)をそれぞれ投与したマウスのLLLT 照射時における脳血流の変化を検討した。またNMDA 受容体拮抗薬であるMK-801を用いて，グルタミン酸興 奮性神経伝達とLLLT照射における血流上昇の関連性を 検討した。LLLT照射中の頭蓋骨表面および脳内の温度 測定を行った。最後に両側頸部頸動脈一過性閉塞モデル (bilateral cervical carotid artery occlusion model: BCCAO model）を用いて，虚血再灌流障害に対するLLLT効果の 検討を行った。照射群と非照射群の残存脳血流の測定お よび, TUNEL (in situ terminal deoxynucleotidyl transferase (TdT)-mediated dUTP-biotin nick end-labeling)染色による 海馬CA-1錐体細胞のアポトーシスの程度を比較した.

経頭蓋LLLTを行うことで照射野に一致した脳血流増 大が観察された。 $1.6 \mathrm{~W} / \mathrm{cm}^{2} \cdot 45$ 分間照射群において最 も効率よく約30\%脳血流を上昇させる事が出来た．組織 学的検討では照射後の脳損傷を示す変化は認めなかっ た。脳組織温度は $1.6 \mathrm{~W} / \mathrm{cm}^{2}$ 照射強度30分間の照射で平 均 $0.8{ }^{\circ} \mathrm{C}$ と小幅に上昇した。 またL-NAME投与群と非投 与群における $1.6 \mathrm{~W} / \mathrm{cm}^{2}$ 照射強度 45 分間照射中の骨表面 の温度変化は両群同等であった。脳組織内NO濃度の変 化は, $1.6 \mathrm{~W} / \mathrm{cm}^{2}$ 照射群は開始直後から $\mathrm{NO}$ の濃度が上昇 し，照射終了直後に速やかに基準值に復帰した。 L-NAME投与群はNO濃度上昇が著しく抑制され, $0.8 \mathrm{~W} / \mathrm{cm}^{2}$ 照射群は $1.6 \mathrm{~W} / \mathrm{cm}^{2}$ のそれと比較し約 $15 \%$ の 濃度上昇のみ得られた。 L-NAME投与群の脳血流は擬照 射群 (sham群) と同程度に抑制され，LLLTによる脳血流 上昇効果は得られなかった。 NMDA受容体と相互作用 があるとされる神経型NOSを抑制する7NI投与群は，15 分の照射では脳血流上昇は得られなかったが，30分，45 分間と照射することでsham群と比較して有意な脳血流 上昇を得た。MK-801投与群では， $1.6 \mathrm{~W} / \mathrm{cm}^{2}$ 強度LLLT 
15分後の血流上昇はコントロール群と同程度であった が，30分，45分と照射を続けた際の脳血流上昇はコント ロール $\left(1.6 \mathrm{~W} / \mathrm{cm}^{2}\right.$ LLLT照射群) と比較して有意差をもっ て抑制された。これら結果から，30分，45分と長時間の LLLTを行う事で得られる脳血流上昇には，神経細胞の 興奮が関与している可能性が示唆された。本研究の結果 から，至適時間のLLLTには中枢神経系の賦活作用があ る可能性が示唆された。後交通動脈がない事が確認され たマウス(コントロール群 : $n=8$, LLLT群 : $n=9$ )につ いてBCCAOモデルを用いて脳虚血再灌流障害に対する $1.6 \mathrm{~W} / \mathrm{cm}^{2}$ LLLTの効果を検討したところコントロール群 と比較し有意差を持って脳血流が維持された。この効果 は照射半球のみならず，非照射半球でも有意差を持って 血流が維持された。ささらLLLT照射群ではCA-1錐体細 胞および照射側皮質のTUNEL陽性細胞がLLLT非照射群 と比較して明らかに減少していた。 以上からLLLTには 虚血再灌流障害に対する神経保護効果があることが明ら かになった。 また $1.6 \mathrm{~W} / \mathrm{cm}^{2}$ LLLTによるDNA損傷の増加 はないことも確認された。

経頭蓋近赤外線レーザー照射によるマウス局所脳血流 の有意な増加を報告し, その作用機序に一酸化窒素が関 与していることを明らかにした。2009年のStrokeに掲載 された大規模前向き無作為二重盲検臨床試験の結果を踏 まえ, 現在NEST-3 trialが予定されている(Effectiveness and safety of transcranial laser therapy for acute ischemic stroke, Stroke 40 (2009) 1359). 我々も，2008年, 学内倫 理委員会に申請し承認を得て, 中枢神経損傷に対する近 赤外光による治療を行っている。マウスinvivoと astrocyte, PC12神経系培養細胞in vitroの基礎的実験で, 近赤外線によって, 細胞外液中の神経伝達物質の glutamateとdopamineが上昇する事を見出した。臨床試験 では, 頭蓋内圧立進と脳へルニアに続発する除脳硬直を 呈し, 外減圧術等で救命し得たが，8ケ月以上，四肢自 動運動無し, 開眼するも追視なく, 従命の全くない40歳 男性に対し, 家族の同意を得て, 前額部にLED (出力 : $13 \mathrm{~mW} \times 23=299 \mathrm{~mW})($ Fig. 2) による低出力近赤外光治 療を朝夕 30 分間 2 回施行した。治療前と 8 週間の治療後の

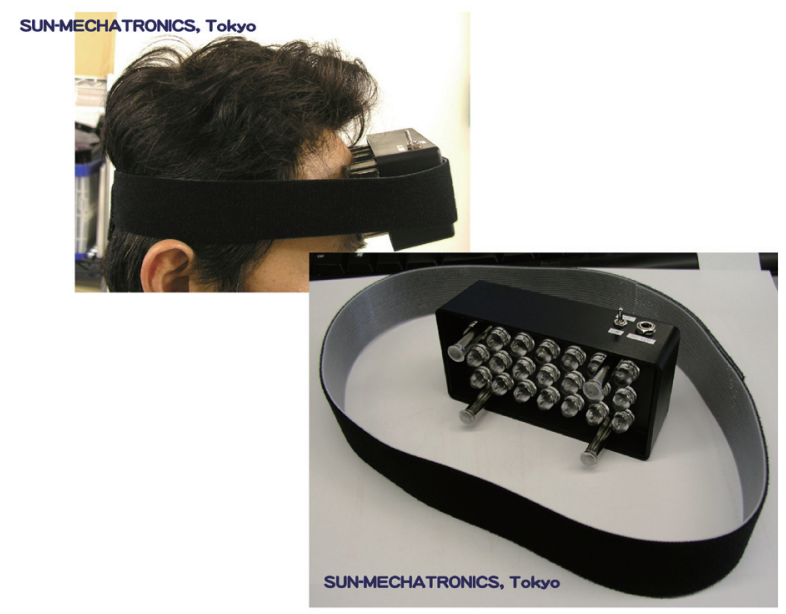

Fig. 2 A photograph of a model being treated, L-light (SUN-MECHATRONICS, Tokyo) .

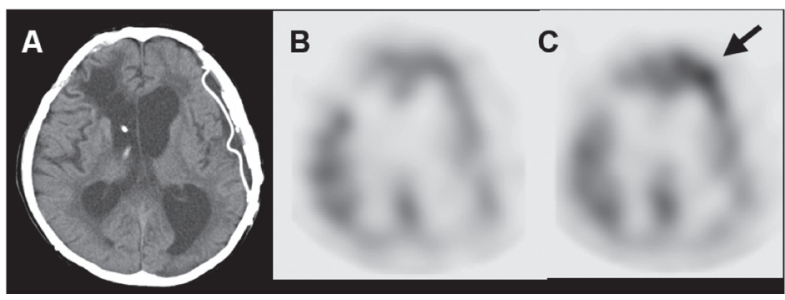

Fig. 3 A computed tomography scan of the head before any light emitting diode (LED) treatments (performed at 220 days post- head trauma), showing a focal low density area in the subcortical white matter, antero-lateral to the right frontal horn; and a ventriculo-peritoneal shunt is in place in the right frontal horn (A). Single-photon emission computed tomography with $\mathrm{N}$-isopropyl [123I]-p-iodoamphetamine (IMP-SPECT) before LED treatment, performed at 227 days post- head trauma (B). IMP-SPECT scan at 30 minutes after the 146th LED treatment. The post- LED SPECT scan was performed 300 days post- head trauma. This post-LED SPECT scan showed a focal increase of $20 \%$, compared with the pre-treatment value of regional cerebral blood flow in the left anterior frontal cortex $(\mathrm{C}$, arrow) .

局所脳血流をIMP-SPECTで定量評価した(Fig. 3)，治療 後，照射部位の頭皮にトラブルは無く，左上肢の自動運 動，合目的運動が出現し，前頭葉脳血流の有意な増加を 認め, acetazolamideに対する脳血流増加効果も改善し た ${ }^{12)}$ 。マウスにおいて認められた, 脳血流増加作用が, 低エネルギー近赤外光を使ってヒトにおいても同様に認 められる可能性が示唆された。最近，うつ病の患者の前 額部に赤外光を照射し, 脳血流を反映するtotal hemoglobinをNIRSで照射中にモニターしたところ, 増 加を認めたが, 有意差には至らなかったとの報告があ る ${ }^{17)}$.ささらなる検討を要する。

\section{5. まとめ}

本研究によって経頭蓋近赤外線レーザー照射はマウス 局所脳血流を上昇させ得ることが判明した。その作用機 序にNOS活性およびNO濃度が関与していることが明ら かとなった，近赤外線レーザーを至適条件で照射する事 で，中枢神経系を活性化させうる可能性があること，ま た虚血再灌流障害に対して神経保護作用がある事も併せ て示された。経頭蓋近赤外線レーザー照射は，今後，脳 循環の基礎的，臨床的研究のtoolとして期待される.

\section{参考文献}

1) M. R. Hamblin: Proc. SPIE 6846 (2008) 684602-1.

2) J. Kubota: Lasers Med. Sci. 17 (2002) 146.

3) S. Mii, C. Kim, H. Matsui, H. Oharazawa, T. Shiwa, H. Takahashi, and A. Sakamoto: J. Nippon Med. Sch. 74 (2007) 23.

4) J. T. Eells, M. M. Henry, P. Summerfelt, M. T. Wong-Riley, E. V. Buchmann, M. Kane, N. T. Whelan, and H. T. Whelan: Proc. Natl. Acad. Sci. USA 100 (2003) 3439.

5) A. Oron, U. Oron, J. Chen, A. Eilam, C. Zhang, M. Sadeh, Y. Lampl, J. Streeter, L. DeTaboada, and M. Chopp: Stroke 37 (2006) 2620 
6) P. A. Lapchak, J. Wei, and J. A. Zivin: Stroke 35 (2004) 1985.

7) P. A. Lapchak, M. K. Han, K. F. Salgado, J. Streeter, and J.A. Zivin: Stroke 39 (2008) 3073.

8) J. C. Rojas, J. Lee, J. M. John, and F. Gonzalez-Lima: J. Neurosci. 28 (2008) 13511.

9) V. E. Shaw, S. Spana, K. Ashkan, A. L. Benabid, J. Stone, G. E. Baker, and J. Mitrofanis: J. Comp. Neurol. 518 (2010) 25.

10) S. Rochkind, D. El-Ani, Z. Nevo, and A. Shahar: Lasers Surg. Med. 41 (2009) 277.

11) Y. Uozumi, H. Nawashiro, S. Sato, S. Kawauchi, K. Shima, and M. Kikuchi: Lasers Surg. Med. 42 (2010) 566.

12) H. Nawashiro, K. Wada, K. Nakai, and S. Sato: Photomed. Laser Surg. (2011) Nov 2. [Epub ahead of print].

13) T. Karu: Ten Lectures on Basic Science of Laser Phototherapy (Grangesberg, Sweden, Prima Books, 2007).
14) S. Benedicenti, I. M. Pepe, F. Angiero, and A. Benedicenti: Photomed. Laser Surg. 26 (2008) 451.

15) Y. Lampl, J. A. Zivin, M. Fisher, R. Lew, L. Welin, B. Dahlof, P. Borenstein, B. Andersson, J. Perez, C. Caparo, S. Ilic, and U. Oron: Stroke 38 (2007) 1843.

16) J. A. Zivin, G.W.Albers, N. Bornstein, T. Chippendale, B. Dahlof, T. Devlin, M. Fisher, W. Hacke, W. Holt, S. Ilic, S. Kasner, R. Lew, M. Nash, J. Perez, M. Rymer, P. Schellinger, D. Schneider, S. Schwab, R. Veltkamp, M. Walker, J. Streeter, and NeuroThera Effectiveness and Safety Trial-2 Investigators: Stroke 40 (2009) 1359.

17) F. Schiffer, A. L. Johnston, C. Ravichandran, A. Polcari, M. H. Teicher, R. H. Webb, and M. R. Hamblin: Behav. Brain Funct. 5 (2009) 46 .
LLLT(低レベルレーザー治療) (low-level laser therapy) American National Standards Institute (ANSI) の基準で

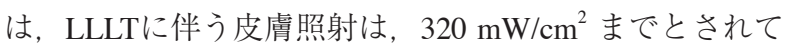
いる. LLLTに関してはTechnology Assessment May 3, 2004 Grace Wang Office of the Medical Director, Department of Labor and Industriesを参照することをお勧めする。疼痛 緩和や手根管症候群に有効であることが示されている。
さらに創傷治癒を促進する可能性もある。しかしなが ら, その機序に関しては, 未解明な点が多く, 照射線量 と生物学的効果の関連性も不明確である。非侵襲的で生 体に有益である可能性が注目されているが, 基礎的研究 を含めてさらなる解明が必要である.

(苗代弘) 